\title{
Nurses' Knowledge Level about High-Alert Medications
}

\author{
Hemșirelerin Yükesek Riskli İlaçlar Hakkemdaki Bigi Düzeyleri
}

\section{Ülkü GÜNEŞ1@, Huri ÖZTÜRK²*iD), Elçin EFTELİ ${ }^{3}$}

${ }^{1}$ Ege University, Faculty of Nursing, Department of Fundemantals of Nursing, İzmir, Turkey ${ }^{2}$ Swansea University, College of Human and Health Sciences, Department of Nursing, Swansea, United Kingdom ${ }^{3}$ Burdur Mehmet Akif Ersoy University, Faculty of Health Sciences, Department of Nursing, Burdur, Turkey

\begin{abstract}
This study was conducted to investigate nurses' knowledge of high-alert medications. Nurses' Knowledge of High-Alert Medications Questionnaire was used to evaluate nurses' knowledge level in a university hospital's clinics where high-alert medications were frequently administered. The questionnaire items, which have two subscales, "drug administration" and "drug regulation", were rated on a 3-point Likert type scale. The study population comprised 187 nurses, and the study sample included 77 nurses as the response rate was $57 \%$. The correct response rate was $61 \%$ for the "Drug administration" subscale and $62.1 \%$ for the "Drug regulation" subscale. The item with the lowest correct response rate $(7.8 \%)$ in the "Drug administration" subscale was "Chemotherapeutic drugs' doses should be calculated according to body surface area in adults and according to body weight in children". The item with the lowest correct response rate $(10.4 \%)$ in the "Drug regulation" subscale was "For pediatric dosage calculations, teaspoon units should be used". The present study results supported the assumption that nurses' knowledge of high-alert medications is inadequate.
\end{abstract}

Keywords: High-Alert Medications, Medication Error, Nursing

Öz: Bu çalışma, hemşirelerin yüksek riskli ilaçlar hakkındaki bilgilerini araştırmak için yapılmıştır. Değerlendirmede Hemşirelerin Yüksek Riskli İlaç Bilgisi anketi bir üniversite hastanesinin yüksek riskli ilaçların sıklıkla uygulandığ1 kliniklerinde kullanılmıştır. Ölçeğin "illaç yönetimi” ve "ilaç düzenleme” olmak üzere iki alt ölçeğinin maddeleri 3'lü Likert tipi bir ölçekle derecelendirilmiştir. Çalışma popülasyonu 187 hemşireden oluşmaktadır ve yanıt oranı \% 57 olduğu için 77 hemşire araştırma örneklemini oluşturmuştur. Doğru yanıt oranı "ilaç yönetimi” alt ölçeği için \% 61 ve "ilaç düzenlemesi”" alt ölçeği için \% 62.1'dir. İlaç uygulama alt ölçeğinde "Kemoterapötik ilaçların dozları yetişkinlerde vücut yüzey alanına ve çocuklarda vücut ağırlığına göre hesaplanmalıdır” ifadesi en düşük doğru yanıt oranına $(\% 7,8)$ sahip maddedir. İlaç düzenlemesi alt ölçeğinde "Pediatrik doz hesaplamalanı için çay kaşığı birimleri kullanılmalıdır" ifadesi en düşük doğru yanıt oranına $(\% 10,4)$ sahip madde olmuştur. Bu çalışmanın sonuçları, hemşirelerin yüksek riskli ilaçlar hakkındaki bilgilerinin yetersiz olduğu varsayımını desteklemektedir.

\begin{tabular}{ll}
\hline Anahtar Kelimeler: Yüksek Riskli İlaçlar, İlaç Hatası, Hemşirelik. \\
\hline${ }^{*}$ Corresponding author : Huri ÖZTÜRK & e-mail : huriozturk@yandex.com \\
Geliş tarihi / Received : 07.10 .2020 & Kabul tarihi / Accepted: 15.03.2021 \\
\hline
\end{tabular}

\section{Introduction}

Although one of the National Patient Safety Goals is improving high-alert medications' safety, ensuring drug safety remains a severe problem among health professionals (Tang et al., 2007; Lu et al., 2013). One of the main reasons for nurses' medication errors is a lack of relevant knowledge (Lu et al., 2013). Medication errors, mostly, may not lead to severe harm, but misadministration of high-alert medications can lead to the patient's death (Hsaio et al., 2010; Institute for Safe Medication Practices (ISMP), 2015).

Institute for Safe Medication Practices (ISMP) identified that the first five high alert medications are "insulin, opiates and narcotics, injectable concentrated potassium chloride, intravenous (IV) anticoagulants, and chloride solutions above 0.9\%" (Belknap, 2001, pp. 339; ISMP, 2017). Based on this medication classification, studies (Franke et al., 2009; Otero et al., 2014) have been conducted to make these high-alert medication 
groups specific for patient groups. These drugs are potentially harmful, even when they are administered appropriately. Therefore, high-alert medications should be administered under supervision, and there are essential points to be taken into consideration during implementation (Lu et al., 2013).

One of the most critical issues that can cause harm to the patient during the intravenous administration of high-alert medications is the method of drug administration (Hicks et al., 2004). Studies have shown that the factor leading to errors during high-alert medications administration is administering the drug at the wrong rate. Hicks et al. (2004) showed that 6.2\% of the medication errors were due to misadministration techniques. The cause of $97 \%$ of the 265 IV medication errors was administering drugs faster than the recommended rate. Hsaio et al. (2010) pointed out that the administration of concentrated electrolytes or epinephrine at a high rate could cause harm to the patient. They reported that nurses' knowledge levels in this regard should be assessed.

Besides the administration rate, the drug administration technique includes other factors, such as route, timing, and administration dose. In their medication error analysis, Hicks et al. (2004) reported that $1.9 \%$ of the errors were due to incorrect dosing and $2.6 \%$ were due to the administration's incorrect route. Nurses' inadequate skills to calculate drug doses increase the incidence of errors occurring during the preparation of infusions by $15-49 \%$ (Parshuram et al., 2008).

In addition, the storage of high-alert medications in easily accessible areas, keeping look-alike and sound-alike medications together, lack of warning labels on medicines, and the use of illegible handwriting and inappropriate abbreviations cause many avoidable errors (Hsaio et al., 2010; Lu et al., 2013). The precautions to be taken differ depending on the group the high-alert medication belongs to (Lo, et al., 2013). These precautions include the regulation and storage of high-alert medications (Lu et al., 2013). For example, the storage of insulin and heparin vials in the same place may lead to confusion. Neuromuscular blocking agents and concentrated electrolytes should not be stored together with other routine stocks in easily accessible areas (Paparella, 2004; Loria, 2012). Narcotics should be stored in double-locked cabinets by two separate staff (Cohen et al., 2007). Not to confuse look-alike and sound-alike medications, verbal orders should not be accepted; they should be stored at different cabinets, different product labels should be used for different products, reminders or alarms should be used. Independent double-check and bar-code systems should be used, and possible errors should be reported (Tuohy and Paparella, 2005; Cohen et al., 2007).

Although many nurses frequently use high-alert drugs in the care, studies show that nurses do not have sufficient knowledge about high-alert drug administrations (Tang et al., 2007; Hsaio et al., 2010; Sahmsuddin and Safie, 2012; Lu et al., 2013). Only one study (Kucukakca and Ozer, 2016) has been conducted to assess nurses' knowledge of high-alert medications in our country. Therefore, this study aims to determine the knowledge level on high-alert medications of the nurses who work in a university hospital's intensive care units and emergency services.

\section{Materials and Methods}

This descriptive study was conducted between February 2016 and January 2017 in a university hospital. The nurses were recruited from a university hospital's intensive care units of neurology, internal medicine, neurosurgery, general surgery, anaesthesia and reanimation clinics and emergency services $(\mathrm{N}=187)$. The study comprised nurses working only in these units as high-alert medications are mostly used in the hospital's internal medicine clinic, surgical clinic, and emergency departments. Nurses with less than six months of experience were excluded from the study. One hundred thirty-six eligible nurses were enrolled in the study. Thirty of them refused to participate in the study, and 29 nurses were on leave. When those were excluded, the study was completed with 77 nurses. The response rate of the study was $57 \%$ of the sample. 
Data were collected using the sociodemographic characteristic form, including age, gender, years of experience in nursing and clinic and Nurses' Knowledge of High-Alert Medications Questionnaire by closed envelope method. Hsaio et al. (2010) developed this questionnaire consisted of 20 questions divided into two parts: In part A, there are ten questions examining drug administration such as drug delivery routes and dosage. In part $\mathrm{B}$, there are questions on how highalert medications should be stored, regulated and prescribed. The items in both sections are rated as "true", "false", and "I do not know".

The questionnaire was translated into Turkish after author permission was received from Hsaio et al. (2010) by four nursing instructors and one English language specialist. The researchers reviewed all translated versions to develop the tool in Turkish. Then, the English language specialist translated the initial version of the questionnaire back into English. The questionnaire statements were drawn between the original English text statements and translated text from Turkish into English, and revisions that considered necessary were made. The questionnaire's clarity and relevance to the topic were evaluated by five academics and five nurses who were experts in their fields. Each expert rated the form's content using a 3-point Likert scale (3: appropriate, 2: I have no idea, 1 : inappropriate).

At the end of the assessment, three items whose content validity index value was lower than 0.62 were removed from the scale, and the questionnaire included 17 items. The items removed from the questionnaire were items 5, 9, and 10 in Part B. Reliability analysis was conducted to determine the questionnaire's internal consistency. Cronbach's alpha was 0.63 for part A and 0.74 for part $\mathrm{B}$.
The data were analyzed with SPSS 22.0 (Statistical Package for the Social Sciences Version 22.0). Statistical advice was obtained from a statistician to analyze the data. The sample was analyzed using the descriptive statistics used to describe the sample characteristics. Frequencies and percentages were used to describe the correct answer rates.

Study approvals were obtained from the Scientific Research and Publication Ethics Committee of the University (27344949-605.01-25785) and the hospital (69631334-044-23454), where the study was to be conducted. The participating nurses were informed about the aim of the study, and their verbal consents were obtained. The participants were assured that they could refuse to participate in or withdraw from the study at any time, and the data were rendered anonymous.

\section{Results}

As shown in Table 1, of the 77 participants, 64 were women, 13 were men, and their mean age was $29.51 \pm 5.60$ years. Of the nurses, $\% 49.3$ had $1-5$ years of experience in nursing. A total of 17 questions were answered by 77 nurses (response rate $57 \%$ ), with an average overall correct answer rate of $65.5 \%$.

While of the participants, $61 \%$ chose the correct options in Part A (Drug administration), 24.9\% chose the wrong options and $14 \%$ chose the option "I do not know". Of the nurses, 89.6\% chose the correct option for the item that "cc or $\mathrm{mL}$ is the dosage expression for insulin injection", $85.7 \%$ for the item that "10\% Ca gluconate, and $10 \% \mathrm{CaCl}_{2}$ are the same drug and can be used interchangeably, and $84.4 \%$ for the item that "when an emergency such as ventricular fibrillation happens, push fast $15 \% \mathrm{KCl} 10 \mathrm{~mL}$ into IV". 
Table 1. Distribution of correct responses by the sociodemographic characteristics of the nurses.

\begin{tabular}{|c|c|c|c|c|c|}
\hline \multirow[t]{2}{*}{ Variable } & \multirow[b]{2}{*}{$\mathbf{n}$} & \multicolumn{4}{|c|}{ Correct Answers } \\
\hline & & $(\%)$ & $\bar{X}$ & SD & P value \\
\hline \multicolumn{6}{|l|}{ Gender } \\
\hline Female & 64 & 83.1 & 11 & 2.21 & \multirow[t]{2}{*}{0.22} \\
\hline Male & 13 & 16.9 & 11.84 & 2.64 & \\
\hline \multicolumn{6}{|l|}{ Age (years) } \\
\hline $20-25$ & 18 & 23.4 & 9,88 & 3,23 & \multirow{4}{*}{0.024} \\
\hline $25-30$ & 31 & 40.3 & 11.35 & 1.76 & \\
\hline $31-35$ & 19 & 24.6 & 11.31 & 1.76 & \\
\hline$>36$ & 9 & 11.7 & 12.55 & 1.74 & \\
\hline \multicolumn{6}{|l|}{ Education } \\
\hline License & 73 & 94.8 & 11.07 & 2.23 & \multirow{2}{*}{0.14} \\
\hline MSc & 4 & 5.2 & 12.25 & 2.36 & \\
\hline \multicolumn{6}{|l|}{ Nursing experience } \\
\hline 6 months- 1 year & 10 & 13 & 11,60 & 2.71 & \multirow{4}{*}{0.17} \\
\hline $1-5$ years & 38 & 49.3 & 10.65 & 1.66 & \\
\hline $6-10$ years & 17 & 22.1 & 11.17 & 1.91 & \\
\hline$>10$ years & 12 & 15.6 & 12.25 & 2.45 & \\
\hline \multicolumn{6}{|l|}{ Length of service in the clinic } \\
\hline 6 months- 1 year & 28 & 36.4 & 10.46 & 3.04 & \multirow{4}{*}{0.18} \\
\hline $1-5$ years & 30 & 39 & 11.50 & 1.40 & \\
\hline $6-10$ years & 13 & 16.8 & 11.23 & 1.87 & \\
\hline$>10$ years & 6 & 7.8 & 12.33 & 2.16 & \\
\hline \multicolumn{6}{|l|}{ Clinic } \\
\hline Emergency & 34 & 44.1 & 11.26 & 2.81 & \multirow{6}{*}{0.90} \\
\hline Anesthesia \& Reanimation IC & 10 & 13.0 & 11.50 & 0.97 & \\
\hline Neurosurgery IC & 10 & 13.0 & 10.70 & 1.70 & \\
\hline Neurology IC & 6 & 7.8 & 11.50 & 1.22 & \\
\hline Internal Medicine IC & 7 & 9.1 & 11.28 & 2.36 & \\
\hline General Surgery IC & 10 & 13.0 & 10.50 & 2.46 & \\
\hline
\end{tabular}

In this part, the item with the lowest correct response rate $(7.8 \%)$ was "chemotherapeutic drugs' doses should be calculated according to body surface area in adults and according to body weight in children". Many participating nurses (64.8\%) did not know that the port A route should not be used for blood drawing or drug administration (Table 2).

While of the participants, $62.1 \%$ chose the correct options in Part B (Drug regulation), 33\% chose the wrong options, and $4.8 \%$ chose the option "I do not know". In this part, the item with the lowest correct response rate $(10.4 \%)$ was "For pediatric dosage calculations, teaspoon units should be used". While $22.1 \%$ of the nurses correctly knew that the term "unit" should not be abbreviated as "U" in the dose expression, $96.1 \%$ of the nurses accurately knew that distinctive labels should be used for look-alike drugs (Table 2).

A statistically significant relationship was found between the number of correct responses given by the participating nurses and their ages $(\mathrm{F}=3.34$, $\mathrm{p}<0.05)$. There was no significant relationship between the number of correct answers provided by the participating nurses and the variables such as gender, education level, length of service in the clinic $(\mathrm{p}>0.05)$. 
Table 2. Ranking of knowledge of drug administration (Part A) and drug regulation (Part B) by correct answer rate $(\mathrm{n}=77)$.

\begin{tabular}{|c|c|c|c|c|c|}
\hline Item & Question & $\begin{array}{l}\text { Correct } \\
\text { Option } \\
(\mathrm{T} / \mathrm{F})\end{array}$ & $\begin{array}{l}\text { Correct } \\
\text { Responses } \\
(\%)\end{array}$ & $\begin{array}{l}\text { Wrong } \\
\text { Responses } \\
\text { / do not } \\
\text { know }(\%) \\
\end{array}$ & Rank \\
\hline \multicolumn{6}{|l|}{ Part A } \\
\hline 4 & $\begin{array}{l}\text { "cc" or "mL" is the dosage expression for } \\
\text { insulin injection }\end{array}$ & $\mathrm{F}$ & 89.6 & $9.1 / 1.3$ & 1 \\
\hline 3 & $\begin{array}{l}10 \% \text { Ca gluconate and } 10 \% \mathrm{CaCl}_{2} \text { are the } \\
\text { same drug and "can be used } \\
\text { interchangeably" }\end{array}$ & $\mathrm{F}$ & 85.7 & $0 / 14.3$ & 2 \\
\hline 6 & $\begin{array}{l}\text { When an emergency such as ventricular } \\
\text { fibrillation happens, push fast } 15 \% \mathrm{KCl} 10 \\
\mathrm{~mL} \text { into IV }\end{array}$ & $\mathrm{F}$ & 84.4 & $6.5 / 9.1$ & 3 \\
\hline 2 & $\begin{array}{l}\text { When an emergency happens, fast IV push } \\
10 \% \mathrm{CaCl}_{2} 10 \mathrm{~mL} \text { in } 1-2 \text { minutes }\end{array}$ & $\mathrm{F}$ & 71.4 & $16.9 / 11.7$ & 4 \\
\hline 8 & $\begin{array}{l}\text { Insulin syringe can be replaced by } 1 \mathrm{~mL} \\
\text { syringe }\end{array}$ & $\mathrm{F}$ & 71.4 & $23.4 / 5.2$ & 5 \\
\hline 9 & $\begin{array}{l}\text { Fast IV infusion of } 3 \% \mathrm{NaCl} 500 \mathrm{~mL} \text { for } \\
\text { patient who has low sodium level }\end{array}$ & $\mathrm{F}$ & 63.6 & $32.5 / 3.9$ & 6 \\
\hline 1 & $\begin{array}{l}\text { Fast IV push 1:1000 epi } 1 \mathrm{amp} \text { for patient } \\
\text { who has mild allergic reaction }\end{array}$ & $\mathrm{F}$ & 61 & $15.6 / 23,4$ & 7 \\
\hline 7 & $\begin{array}{l}15 \% \mathrm{KCl} \text { better added to Ringer's solution } \\
\text { for rapid infusion }\end{array}$ & $\mathrm{F}$ & 45.5 & $19.5 / 35.1$ & 8 \\
\hline 10 & $\begin{array}{l}\text { Port-A route can be used for blood } \\
\text { withdrawal and drug injection generally }\end{array}$ & $\mathrm{F}$ & 29.9 & $64.9 / 5.2$ & 9 \\
\hline 5 & $\begin{array}{l}\text { Chemotherapeutic drugs' doses should be } \\
\text { calculated according to body surface area in } \\
\text { adults and according to body weight in } \\
\text { children }\end{array}$ & $\mathrm{F}$ & 7.8 & $61.0 / 31.2$ & 10 \\
\hline \multicolumn{6}{|l|}{ Part B } \\
\hline 2 & Use distinctive labeling on look-alike drugs & $\mathrm{T}$ & 96.1 & $2.6 / 1.3$ & 1 \\
\hline 1 & $\begin{array}{l}\text { Use "Amp" or "Vial" for dose expression } \\
\text { instead of "mg" or "gm" }\end{array}$ & $\mathrm{F}$ & 94.8 & $3.9 / 1.3$ & 2 \\
\hline 4 & $\begin{array}{l}\text { For convenience, heparin and insulin } \\
\text { should be stored together in the } \\
\text { refrigerator }\end{array}$ & $\mathrm{F}$ & 87.0 & $10.4 / 2.6$ & 3 \\
\hline 7 & $\begin{array}{l}15 \% \mathrm{KCl} \text { is frequently used, so it should be } \\
\text { easily and freely accessed by nurses }\end{array}$ & $\mathrm{F}$ & 64.9 & $29.9 / 5.2$ & 4 \\
\hline 6 & $\begin{array}{l}\text { If patient can tolerate, potassium can be } \\
\text { administered orally instead of IV route }\end{array}$ & $\mathrm{T}$ & 59.7 & $31.2 / 9.1$ & 5 \\
\hline 3 & $\begin{array}{l}\text { "U" is used instead of "unit" to express the } \\
\text { amount of doses }\end{array}$ & $\mathrm{F}$ & 22.1 & $74 / 3.9$ & 6 \\
\hline 8 & $\begin{array}{l}\text { For pediatric dosage calculations, teaspoon } \\
\text { units should be used }\end{array}$ & $\mathrm{F}$ & 10.4 & $79.2 / 10.4$ & 7 \\
\hline
\end{tabular}




\section{Discussion}

In the present study, $90 \%$ of the nurses answered correctly that "cc" or " $\mathrm{mL}$ " should not be used as a unit of dose measurement in insulin injections, and $74 \%$ of them were aware that $1 \mathrm{~mL}$ injectors should not be used as an insulin injector. Similar results were reported by Hsaio et al. (2010) and Lu et al. (2013). Although nurses have this knowledge, they are still forced to apply insulin injections using $1 \mathrm{~mL}$ injectors or tuberculin injectors in our experiences. Although most insulin products come from companies in 100 units / mL, due to the recent increase in obesity, insulin resistance, and the use of insulin pumps, the use of 500 units $/ \mathrm{mL}$ insulin has also begun to increase. However, clinics do not have an insulin injector designed to measure 500 units of insulin dose. Therefore, the nurses have to administer 500 units of insulin using 100 units / mL insulin injectors, tubercle injectors or $1 \mathrm{~mL}$ injectors. This leads to the administration of insulin in high doses (Prescrire International, 2014).

It is reported that $26 \%$ of patient safety incidents related to insulin were caused by administering the wrong insulin dose and resulted in severe harm and deaths (Sharpe, 2012). Therefore, companies must produce injectors suitable for high-dose insulin products for patients to receive the appropriate dose of medicine. Insulin should be administered only with insulin injectors, and all healthcare professionals should be informed and trained about such errors.

Concentrated electrolytes come at the top of highalert medications and errors made during these medications' administration lead to fatal outcomes in patients treated with medications. When these solutions are administered as an IV bolus injection, they bring severe consequences. For instance, 15\% $\mathrm{KCl}$ may cause cardiac arrest (Grissinger, 2011; Gyeongae, 2014). In the present study, one-third of the nurses did not choose the correct option for the item that $" 3 \% \mathrm{NaCl}$ and $10 \% \mathrm{CaCl}_{2}$ solutions should not be administered fast", and more than half of them $(55 \%)$ did not choose the correct option about how 15\% $\mathrm{KCl}$ should be administered. Similar results have been reported in other studies (Hsaio et al., 2010; Chen et al., 2014). Hsaoi et al. (2010) also showed that more than $30 \%$ of the nurses did not understand that "15\% $\mathrm{KCl}$ should not be administered by IV bolus under any circumstances". These results show that more time should be allocated to pharmacology lessons in nursing education and that this information should be updated with in-service training when necessary.

In this part, the item with the lowest correct response rate $(7.8 \%)$ was "Chemotherapeutic drug doses should be calculated according to body surface area in adults and according to body weight in children". The low correct answer rates related to the same issue were reported in Hsaio et al.'s (2010) and Lu et al.'s (2013) studies too (24.6\%, $33.3 \%$, respectively). Chemotherapy drugs are included in the high-alert medications classification, and doses of these drugs are of great importance in terms of the treatment's efficacy (Yu et al., 2013). Body surface area is a variable with a difficult constitutional body and physiological assessment (Geriņa-Bērziņa et al., 2013). Despite some limitations, it remains the most commonly used parameter regarding chemotherapy of cancer patients. The dosage of chemotherapeutic drugs has been based on the patients' physiologic variables related to drug metabolism and elimination, such as basal metabolic rate, renal function and hepatic function. It varies by individuals' body surface area (Sacco et al., 2010). It is reported that medication errors occur with high incidence (44\%) in chemotherapy due to the lack of specific knowledge and training of health professionals in chemotherapy, prescription, preparation and administration. It leads to fatal patient safety incidences, such as chemotherapy overdose or dose calculation errors (Khan et al., 2012; Yu et al., 2013). Nurses, therefore, should have adequate knowledge and training about chemotherapy in nursing school and throughout the in-hospital continuing education.

Of the nurses, $64.9 \%$ chose the correct option for the item $15 \% \mathrm{KCl}$ is frequently used, so nurses should easily and freely access it. However, about one-third of the nurses $(35.1 \%)$ in the present 
study do not know the correct answer was shocking. In 2002, in line with the national patient safety goals, concentrated electrolytes were removed from the patient care units unless clinically necessary, and nurses' easy access to this medication was prevented. This measure mentioned above was taken due to tragic errors such as fast intravenous administration of concentrated potassium made by nurses because they lacked the necessary knowledge. Although potassium chloride is removed from clinics, nurses in hospitals where 24-hour pharmacy service is not available are able to get this medication from the drug cabinets at nights and on weekends. Therefore, this drug still poses a threat to patient safety in clinics (Grissinger, 2011). Although limited access to potassium chloride has reduced fatal errors, nurses should be aware of the risks associated with the use of this drug. The results of the present study support the view that nurses should be educated about the subject.

Of the participating nurses, $74 \%$ chose the incorrect option for the item " $\mathrm{U}$ is used instead of the unit to express the amount of doses". Similarly, the incorrect response rate in Hsaio et al.'s (2010) study was $62.3 \%$. Administration of insulin, a vital drug for patients with diabetes, in high doses results in hypoglycemia, coma and death, and in low doses results in hyperglycemia and ketoacidosis. Insulin administration errors usually occur due to the use of abbreviations when medication orders are given. The use of ' $U$ ' instead of 'unit' often results in a 10-fold overdose because ' $\mathrm{U}$ ' is mistaken for ' 0 '. In addition, using $1 \mathrm{~mL}$ injectors as an insulin injector leads to the administration of insulin in overdoses (ISMP, 2015). These results indicate that more attention should be given to nursing education and that nurses' knowledge should be strengthened through in-service training.

Many nurses $(79.2 \%)$ in the current study did not know that teaspoon should not be used as a unit in pediatric dosing calculations. The present study results are consistent with those of Hsaio et al.'s study (2010). The most common medication error in paediatrics and neonatal units is the dose calculation errors. In the US, each year, more than
70,000 children are admitted to emergency departments due to "medication overdoses" (Franke et al., 2009). Medication overdose is associated with the use of inappropriate dosemeasuring devices (Neville et al., 2015). Yin and colleagues (2014) reported that $39.4 \%$ of parents made an error in measuring the intended dose. When medicine is given with teaspoons or dessertspoons of different sizes, children can receive a medication overdose or underdose. The medication overdose can bring about consequences as severe as liver failure. If the child gets a medication underdose, then he/she has to take the medication in shorter periods because the desired effect is not achieved in the child. Therefore, when children are administered medicines, injectors or measuring spoons must be used. Although these errors are mostly known as errors made by parents, it is noteworthy that nurses who are health professionals did not know that teaspoons/dessertspoons should not be used as a dose-measuring device (Yin et al., 2014). These errors may be due to the widespread use of spoons because the measuring spoons provided with liquid medicine cannot always be kept in the medicine carton package. Our study results support that this issue should be emphasized more in nursing education.

While such sociodemographic characteristics of the participating nurses as sex, education level, length of employment and the clinics they worked in did not affect the number of correct responses they gave (all $\mathrm{p}>0.05$ ). There was only a significant correlation between the nurses' age and correct responses $(F=3.34, p<0.05)$. Similarly, in the literature, a significant relationship has been determined between the nurses' age and their knowledge levels (Lu et al., 2013, Hsaio et al., 2010). Although no statistically significant correlation was determined between the participants' length of service and their knowledge levels, the nurses with more than ten years of length of service had a higher number of correct responses. Similar studies have also shown that as the length of service increases, so does the number of correct responses. Besides, nurses' education level might have affected the knowledge level in the present study; of the participants, $93.5 \%$ had 
an undergraduate degree, which is thought to yield this result.

\section{Conclusions}

The study had some limitations, as the sample included nurses working in only one university hospital, so the results cannot be generalized. Our results should be interpreted with great caution due to biased sampling. Also, while filling out the questionnaires, the participants may have been influenced by each other; therefore, their answers may not reflect their actual responses.

Despite these limitations, the current study results support the view that nurses' knowledge of highalert medications is inadequate. The majority of the nurses lack information, especially about chemotherapeutic drugs' doses, pediatric dosage calculations and unite. Nurses' knowledge of highalert medications should be updated via in-service training, and that the time allocated to pharmacology courses in the nursing curriculum should be increased.

\section{Ackowledments}

Special thanks to all of nurses who agreed to participate in this study.

The article was previously presented as this research's abstract on 4th Primary Nursing Care Conference, 25-27 May 2017 in Turkey.

\section{References}

Belknap, S., 2001. High-alert'medications and patient safety. International Journal for Quality in Health Care, 13(4), 339-340.

Chen, M.J., Yu, S., Chen, I.J., Wang, K.W.K., Lan, Y.H., Tang, F.I., 2014. Evaluation of nurses' knowledge and understanding of obstacles encountered when administering resuscitation medications. Nurse Education Today, 34(2), 177-184. doi:10.1016/j.nedt.2013.04.011

Cohen, M.R., Smetzer, J.L., Tuohy, N.R., and Kilo, C.M., 2007. High-alert medications: safeguarding against errors. In:Cohen, M.R. (Ed), Medication Errors. Washington (DC): American Pharmaceutical Association, pp. 317-411
Franke, Hillary A., Donna M.W., Jane L.H., 2009. High-alert medications in the pediatric intensive care unit. Pediatric Critical Care Medicine, 10(1): 85-90. doi: 10.1097/PCC.0b013e3181936ff8

Geriņa-Bērziña, A., Vikmanis, U., Purkalne, G., Umbraško, S., 2013. Body composition characteristics and body surface area. Papers on Anthropology, 22, 3440. doi: 10.12697/poa.2013.22.04

Grissinger, M., 2011. Potassium chloride injection still poses threats to patients. Pharmacy and Therapeutics, 36(5), 241-302.

GyeongAe, S., 2014. Errors in high-risk intravenous injections administered by nurses: The causes according to healthcare professionals. Health Science Journals, 8(2), 249-261.

Hicks, R.W., Cousins, D.D., Williams, R.I. 2004. Selected medication-error data from USP's MEDMARX program for 2002. American Journal of Health-System Pharmacy, 61(10), 993-1000.

Hsaio, G.Y., Chen, I.J., Yu, S., Wei, I.L., Fang, Y.Y., Tang, F.I., 2010. Nurses' knowledge of highalert medications: instrument development and validation. Journal of Advanced Nursing, 66(1), 177190. doi: 10.1111/j.1365-2648.2009.05164.x

ISMP, 2015. ISMP's List of Error-Prone Abbreviations, Symbols, and Dose Designations, 2015.

www.ismp.org/Tools/errorproneabbreviations.pdf (Accessed 10.02.2017).

ISMP, 2017. ISMP's List of High-Alert Medications. http://www.ismp.org/tools/highalertmedicationLists. asp(Accessed 10.02.2017).

Khan, N., Khowaja, K.Z.A., Ali, T.S., 2012. Assessment of knowledge, skill and attitude of oncology nurses in chemotherapy administration in tertiary hospital Pakistan. Open Journal of Nursing, 2(02), 97. doi:10.4236/ojn.2012.22015

Kucukakca, G., Ozer, N., 2016. Cerrahi kliniklerde calisan hemsirelerin yüksek riskli ilac uygulamalari konusundaki bilgi durumlarinin ve ilac hatalariyla ilgili tutum ve davranislarinin incelenmesi [Investigating Knowledge Levels of Nurses, Working in Surgical Clinics, About High Risk Medicines and Their Attitudes and Behaviors Regarding Medication Errors]. Journal of Anatolia Nursing and Health Sciences, 19(1), 34-41. doi: 10.17049/ahsbd.40884

Lo T.F., Yu S., Chen I.J., Wang K.W.K., Tang F.I., 2013. Faculties' and nurses' perspectives regarding knowledge of high-alert medications. Nurse Education Today, 33(3), 214-221. doi:10.1016/j.nedt.2012.01.004 
Loria, G., 2012. Reduction of harm from high risk medications. Apollo Medicine, 9(2), 160-165. doi: 10.1016/j.apme.2012.05.001

Lu, M.C., Yu, S., Chen, I.J., Wang, K.W.K., Wu, H.F., Tang, F.I., 2013. Nurses' knowledge of highalert medications: a randomized controlled trial. Nurse Education Today, 33(1), 24-30. doi: 10.1016/j.nedt.2011.11.018

National Coordinating Council for Medication Error Reporting and Prevention (NCCMERP) http://www.nccmerp.org/about-medication-errors (Accessed 12.03.2017).

Neville, K., Galinkin, J.L., Green, T.P., Johnson, T.D., Paul, I.M., Sullivan, J., et al., 2015. Metric units and the preferred dosing of orally administered liquid medications. Pediatrics, 135(4), 784-787. doi: 10.1542/peds.2015-0072

Otero M.J., Moreno-Gómez, A.M., Santos-Ramos B., Agra Y., 2014. Developing a list of high-alert medications for patients with chronic diseases. European Journal of Internal Medicine, 25(10): 900908. doi: 10.1016/j.ejim.2014.10.021

Paparella, S., 2004. Avoiding disastrous outcomes with rapid intravenous push medications. Journal of Emergency Nursing, 30(5), 478-480. doi:org/10.1016/j.jen.2004.08.002

Parshuram, C.S., To, T., Seto, W., Trope, A., Koren, G., Laupacis, A., 2008. Systematic evaluation of errors occurring during the preparation of intravenous medication. Canadian Medical Association Journal, 178(1), 42-48. doi: 10.1503/cmaj.061743.

Prescrire Int., 2014. New drugs and indications in 2013: little real progress but regulatory authorities take some positive steps. Prescrire International, 23(148):107-110.
Sacco, J.J., Botten, J., Macbeth, F., Bagust, A., Clark, P., 2010. The average body surface area of adult cancer patients in the UK: a multicentre retrospective study. PloS one, 5(1), e8933. doi:10.1371/journal.pone.0008933

Shamsuddin, A.F., Shafie, S.D., 2012. Knowledge of nurses in the preparation and administration of intravenous medications. Procedia Social and Behavioral Sciences, 60, 602-609. doi: 10.1016/j.sbspro.2012.09.429

Sharpe, L., 2012. Improving safety of insulin administration: A pilot audit of hospital staff knowledge. Journal of Diabetes Nursing, 16(1), 8-16.

Tang, F.I., Sheu, S.J., Yu, S., Wei, I.L., Chen, C.H., 2007. Nurses relate the contributing factors involved in medication errors. Journal of Clinical Nursing, 16(3), 447-57. doi: 10.1111/j.1365-2702.2005.01540.x

Tuohy N., Paparella S., 2005. Look-alike and soundalike drugs: errors just waiting to happen. Journal of Emergency Nursing, 31(6), 569-571 doi:10.1016/j.jen.2005.07.012

Vaismoradi, M., Salsali, M., Turunen, H., Bondas, T., 2013. A qualitative study on Iranian nurses' experiences and perspectives on how to provide safe care in clinical practice. Journal of Research in Nursing, 18(4), 351-365. doi:0.1177/1744987112451578

Yin, H.S., Dreyer, B.P., Ugboaja, D.C., Sanchez, D.C., Paul, I.M., Moreira, H.A., et al., 2014. Unit of measurement used and parent medication dosing errors. Pediatrics, 134(2), e354-e361. doi:10.1542/peds.2014-0395

Yu, H.Y., Yu, S., Chen, I.J., Wang, K.W.K., 2013. Evaluating Nurses' Knowledge of Chemotherapy. Journal of Continuing Education in Nursing, 44(12), 553-563. doi: 10.3928/00220124-20131015-03. 